Journal of Public Policy

http://journals.cambridge.org/PUP

Additional services for Journal of Public Policy:

Email alerts: $\underline{\text { Click here }}$

Subscriptions: $\underline{\text { Click here }}$

Commercial reprints: $\underline{\text { Click here }}$

Terms of use : $\underline{\text { Click here }}$

\title{
Divergence in Growth in Post-Communist Countries
}

Ivan Katchanovski

Journal of Public Policy / Volume 20 / Issue 01 / April 2000, pp 55 - 81

DOI: null, Published online: 08 September 2000

Link to this article: http://journals.cambridge.org/abstract_S0143814X00000751

How to cite this article:

Ivan Katchanovski (2000). Divergence in Growth in Post-Communist Countries. Journal of Public Policy, 20, pp 55-81

Request Permissions : $\underline{\text { Click here }}$ 


\title{
Divergence in Growth in Post-Communist Countries
}

\author{
IVAn KATGHANOVSKI* Public Policy, George Mason University
}

\begin{abstract}
The paper analyzes the divergence of economic growth in post-communist countries along geographical lines. It examines the role of culture, manifested in the form of civil society, social capital, trust, religious and business ethics, and historical experience, in the economic growth. Multivariate regression, a path (structural equation) model, and sensitivity analysis are used to determine direct and indirect effects of culture, policy, corruption, war, initial economic conditions, and ethnicity on the economic growth in 28 post-communist countries in 1990-1998. The statistical analyses show that a cultural index, which reflects civil society strength, the proportion of Catholics and Protestants in the population and historical experience, has the strongest effect on growth, economic reform, macroeconomic stabilization policy and corruption.
\end{abstract}

The former communist countries shared the same type of economic system before the collapse of communism. Communism rule in Eastern and Central Europe, Mongolia, and the former Soviet Union ended around the end of the 1980s and the beginning of the 1990s. Governments in these countries abandoned communist policies and initiated economic reforms. The scope of the reforms and decline of Gross Domestic Product (GDP) have varied significantly among postcommunist countries. The economic reforms have been deeper and more comprehensive and economic decline less severe in Central European countries than in the former Soviet Republics, with the exception of the Baltic States.

This paper analyzes the divergence of the growth levels in postcommunist countries in 1998 compared with 1989. The analysis covers

* I would like to thank David Armor, Gary Becker, Peter Boettke, Francis Fukuyama, Don Lavoie, Seymour Martin Lipset, Richard Rose, Roger Stough, and the four anonymous reviewers for their comments and suggestions on various stages of this project. However, responsibility for any remaining mistakes is my own. 
all 28 post-communist countries in Eastern and Central Europe, the former Soviet Union, and Mongolia. The paper's hypothesis is that cultural differences affect growth in post-communist countries directly and indirectly, via policy, corruption, and involvement in war. Several cultural variables, which refer to civil society development, religious composition of the population, business ethics, historical experience, and trust are identified to distinguish the effects of different aspects of culture on growth. To make the analysis more reliable, a cultural index is created by means of factor analysis.

A major objection to the cross-national studies of economic growth is that countries are not comparable. For example, Haberler (1974, 1718) states that differences in data quality and structure of the economy complicate comparisons between developed, developing, and communist countries. The growth data for the former communist countries are more comparable than for the other countries. The European Bank for Reconstruction and Development (EBRD), the International Monetary Fund (IMF), the World Bank, and the Freedom House, report comparative data on economic growth and development in post-communist countries. However, it should be noted that the growth data are based on statistics collected by the national authorities. The official data tend to overestimate the decline of output in the former communist countries because they largely fail to take into account increase in quality and selection of goods and the rise of the unofficial economy (See Fischer, Sahay, and Vegh, 1996, 61-62, and Rose, 1992). Output measurement in countries, such as Uzbekistan, where economy continues to be dominated by the state is likely to be biased upward (See Taube and Zettelmeyer, 1998).

All communist countries attempted to implement industrialization, collectivization, and mass education policies and institute the state control over the economy in the form of central planning and the state ownership of enterprises (Kornai, 1992). Communist economic planning involved both micro and macro levels. The communist state controlled output, prices, and wages of enterprises and individuals. Economic planning on the macro level included macroeconomic aggregates, such as national income, aggregate wages, and output in different sectors of the economy. Hungary, Poland and Yugoslavia deviated from this model in some aspects. Limited market reforms were implemented in Hungary before the fall of communism. Private farming remained dominant in the agricultural sector in communist Poland and Yugoslavia. Enterprises had a greater autonomy of economic management in Yugoslavia.

Economic conditions at the end of the 1980 os were not the same in all former communist countries. Per capita GDP, repressed inflation, 
and other indicators of initial economic conditions differed in many countries (Table 1). GDP per capita in Albania, Mongolia, Bosnia and Herzegovina, Macedonia, Romania, Kyrgyzstan, Uzbekistan, and Tajikistan was lower than $\$ 35$ oo in 1989 . In contrast, per capita GDP exceeded \$80oo in Slovenia, Czech Republic, Estonia, and Latvia. Repressed inflation during 1987-1990 was much higher in the former Soviet republics than in the other former communist countries.

Communist parties held a monopoly of power in communist countries. This monopoly helped to keep together multi-ethnic communist states: the Soviet Union, Yugoslavia, and Czechoslovakia. The Warsaw Pact dominated by the Soviet Union suppressed conflicts among and within the communist countries. However, communist rule was established in Mongolia and the Soviet Union, with exceptions of the Baltic States, Western Ukraine, Western Belarus and most of Moldova, about three decades earlier than in other countries. In contrast, communist rule ended and market economic reforms started a few years earlier in Central European countries than in the former Soviet Union.

Economic growth in 1998 compared to 1989 varies significantly in the former communist countries. The 1998 real GDP in Poland, Slovenia, Slovakia, Czech Republic, and Hungary either exceeds or is close to exceeding the 1989 level of GDP. In contrast, the 1998 GDP in Moldova, Georgia, Bosnia, Ukraine, Armenia, Azerbaijan, Tajikistan, and Turkmenistan is less than a half of its 1989 level (Table 1).

\section{Literature review and hypothesis}

A substantial body of theoretical and empirical research attempts to explain cross-national growth differences. In the traditional neoclassical growth theory developed by Solow (1956), capital and labor are two factors producing growth. The model leaves a large portion of the growth unexplained. According to Barro (1991, 407), the neoclassical growth model implies that:

a country's per capita growth rate tends to be inversely related to its starting level of income per person. In particular, if countries are similar with respect to structural parameters for preferences and technology, then poor countries would grow faster than rich countries. Thus, there is a force that promotes convergence in levels of per capita income across countries. ${ }^{1}$

However, empirical evidence suggests that some groups of countries converge while others diverge. For example, in East Asian countries, the rate of economic growth has been much higher than in developed Western countries, while in South Asian, Sub-Saharan African and 
TABLE 1: Indicators of economic growth, reform, initial conditions and culture in post-communist countries

\begin{tabular}{|c|c|c|c|c|c|c|c|c|c|}
\hline Country & $\begin{array}{l}1998 \text { real } \\
\text { GDP level } \\
(1989=100 \%)^{1}\end{array}$ & $\begin{array}{l}\text { Economic } \\
\text { reform } \\
\text { index }\end{array}$ & $\begin{array}{l}\text { Repressed } \\
\text { inflation, } \\
19^{8} 7^{-1990^{3}}\end{array}$ & $\begin{array}{l}\text { GDP per } \\
\text { capita, PPP, } \\
\$ 1989^{4}\end{array}$ & $\begin{array}{l}199^{8} \text { price } \\
\text { level }\left(19^{8} 9=1\right)^{5}\end{array}$ & $\begin{array}{l}\text { Proportion of } \\
\text { ethnic minorities, } \\
\text { Percent }^{6}\end{array}$ & $\begin{array}{l}\text { Corruption } \\
\text { index, } \\
1998^{2}\end{array}$ & $\begin{array}{l}\text { Civil society } \\
\text { index } 199^{2}\end{array}$ & $\begin{array}{l}\text { Proportion of } \\
\text { Catholics and } \\
\text { Protestants, } \\
\text { Percent }^{7}\end{array}$ \\
\hline Albania & 86 & $3 \cdot 5^{\circ}$ & $4 \cdot 3$ & 1400 & 20.1 & 5 & 4 & 3.75 & 10 \\
\hline Bulgaria & 65 & $3 \cdot 9^{2}$ & 18 & $5^{000}$ & $1855 \cdot 4$ & 15 & 3 & 4.25 & 1 \\
\hline Croatia & 78 & 4.17 & 12 & 6171 & 1215.1 & 22 & 3 & $4.5^{\circ}$ & 77 \\
\hline Czech Rep. & 95 & 6.00 & -7.1 & 8600 & 3.6 & 6 & 2 & $5 \cdot 5^{\circ}$ & 44 \\
\hline Macedonia & $5^{8}$ & $3 \cdot 33$ & 12 & 3394 & $85^{6.9}$ & 33 & 3 & 4.25 & $\mathrm{o}$ \\
\hline Hungary & 95 & 6.33 & -7.7 & 6810 & 6.3 & 9 & 1 & 6.75 & 93 \\
\hline Poland & 117 & 6.08 & 13.6 & $5^{1} 5^{0}$ & 25.6 & 2 & 1 & 6.75 & 95 \\
\hline Romania & $7^{6}$ & $3 \cdot 5^{\circ}$ & 16.8 & $347^{\circ}$ & 608.1 & 11 & 3 & 4.25 & 12 \\
\hline Slovakia & 100 & $4 \cdot 4^{2}$ & -7.1 & 7600 & 3.6 & 13 & 3 & 5.00 & 68 \\
\hline Slovenia & 103 & 5.83 & 12 & 9200 & 28.1 & 9 & 1 & 6.00 & 72 \\
\hline Estonia & $7^{6}$ & 6.00 & $25 \cdot 7$ & 8900 & 179.7 & 38 & 2 & 5.75 & 68 \\
\hline Latvia & $5^{8}$ & $5 \cdot 5^{\circ}$ & $25 \cdot 7$ & 8590 & 110.9 & $4^{8}$ & 2 & 5.75 & 63 \\
\hline Lithuania & 64 & $5 \cdot 4^{2}$ & $25 \cdot 7$ & 6430 & $433 \cdot 9$ & 20 & 2 & 6.00 & 70 \\
\hline Armenia & $4^{1}$ & $3.9^{2}$ & 25.7 & 5530 & 73086.4 & 6 & 4 & $4 \cdot 5^{\mathrm{O}}$ & o \\
\hline Azerbaijan & 44 & 3.00 & 25.7 & $4^{620}$ & 17489.7 & 17 & 4 & 3.00 & o \\
\hline Belarus & 77 & 1.75 & 25.7 & 7010 & $3^{1} 9^{\circ} 5^{2}$ & 22 & 3 & 2.25 & 14 \\
\hline Georgia & 33 & 4.00 & 25.7 & $559^{\circ}$ & $328443 \cdot 3$ & $3^{0}$ & 3 & 3.75 & $\mathrm{o}$ \\
\hline Kazakhstan & 61 & $3 \cdot 5^{\circ}$ & 25.7 & $5^{130}$ & 50784.8 & $6 o$ & 4 & 3.00 & 5 \\
\hline Kyrgyzstan & 61 & 4.25 & $25 \cdot 7$ & 3180 & 2620.6 & $4^{8}$ & 4 & $3 \cdot 5^{\circ}$ & $\mathrm{o}$ \\
\hline Moldova & 32 & 3.83 & $25 \cdot 7$ & $4^{670}$ & 2267.6 & $3^{6}$ & 3 & 4.25 & o \\
\hline Russia & 55 & 4.08 & $25 \cdot 7$ & 7720 & $1105^{\circ}$ & 18 & 4 & 4.00 & o \\
\hline Tajikistan & $4^{1}$ & 1.87 & 25.7 & 3010 & 297937.2 & 38 & 4 & 2.75 & o \\
\hline Turkmenistan & 44 & $1.5^{8}$ & $25 \cdot 7$ & 4230 & $305054^{6.8}$ & 28 & 4 & 1.00 & o \\
\hline Ukraine & 37 & 3.25 & 25.7 & $5^{680}$ & $205^{6} 7^{6.5}$ & 27 & 4 & 3.75 & 15 \\
\hline Uzbekistan & 88 & 1.75 & 25.7 & $274^{\circ}$ & $2844^{8.8}$ & 29 & 4 & $1.5^{\circ}$ & o \\
\hline Yugoslavia & 53 & 3.17 & 12 & $454^{2}$ & 44976.3 & 37 & 4 & 3.00 & 5 \\
\hline Bosnia & 35 & 1.83 & 12 & 3394 & $35^{8} 45^{264}$ & $5^{6}$ & 3 & 2.00 & 19 \\
\hline Mongolia & 93 & 4.00 & 7.6 & 2100 & $9 \cdot 3$ & 10 & 3 & 4.75 & $\mathrm{o}$ \\
\hline
\end{tabular}

Sources: ${ }^{1}$ EBRD $(1999,6)$. Output, price level, and per capita GDP in Bosnia, Mongolia, and Yugoslavia are estimated from the IMF (1999a), World Bank, and

UNECE (1998) publications and online databases, and the EIU (1995, 1998, and 1999) country studies, ${ }^{2}$ Freedom House index, March 1998 (See Karatnycky, et al., 1998, 15). Economic reform and civil society indexes are reversed ${ }^{3}$ De Melo, et al. (1997). ${ }^{4}$ De Melo and Gelb $(1996,267)$. ${ }^{5}$ Calculated from EBRD (1999, 9) and EBRD (1992). ${ }^{6} \mathrm{CIA}(1992)$ and Bremmer and Taras (1997). ${ }^{7}$ Estimated from CIA (1997), CIA (1992), Worldmark Encyclopedia (1995), and country studies. 
Latin American countries, the rate of growth has been lower than in the West in the 1960-8os (World Bank, 1993).

There is growing literature in economics trying to explain the disparity between the neoclassical growth theory and the empirical data. Some economists include human capital in their models (Lucas, 1988, and Mankiw, 1995). Endogenous growth economists include technology and assume increasing returns in their models (Romer, 1986). Public choice economists add political factors, such as interest groups (Olson, 1982). New institutional economists incorporate property rights and path dependence (North, 1990).

Empirical studies of growth often employ cross-national regressions. Along with capital and labor, these studies include other variables, such as education as a proxy for human capital, inflation, political instability, democracy, population growth, latitude, and regional dummies. Temple $\left(1999,15^{2}\right)$ summarizes their main findings as follows:

A key reason why growth rates differ across countries is that macroeconomic stability differs across countries. ... High inequality lowers growth, perhaps by raising social and political instability. The depth of financial intermediation seems important to subsequent development. Democracies do not do noticeably better than autocratic regimes, but countries that extend economic freedoms and protect property rights grow faster. Big government and high taxation may have a negative effect, but the evidence is still somewhat ambiguous. Government spending on infrastructure is beneficial. Openness to trade also appears to be a good thing, although we do not yet know enough about the conditions under which it is true.

Several studies show that geographic variables are related to growth. Regional dummies improve substantially the explanatory power of cross-national growth regressions. Barro (1991) finds that dummy variables for Sub-Saharan African and Latin American countries are significantly negative for growth rates in 1960-1985. De Long and Summers (1991, 487-490) find that Latin American and East Asian countries have negatively correlated residuals in the 1960-1985 growth regressions. However, they also find that growth in many European countries is not geographically correlated. Bloom and Sachs (1998) attribute poor growth in African countries to their geographical location. La Porta, Lopez-de-Silanes, Shleifer, and Vishny (1999) conclude that latitude is positively related to the government performance. Latitude (distance from the equator) may capture the effect of climate, and regional dummies may capture the spillover effect. However, the geographic variables lack strong theoretical foundations in the social sciences and can reflect the omitted variable problem. ${ }^{2}$ (Temple, 1999, 131, Barro, $1991,435^{-436)}$.

Most of these studies deal with long-term growth and do not include 
the former communist countries (See, for example, Barro, 1991, 440442, and De Long and Summers, 1991, 495-500). However, an increasing number of cross-national studies focuses specifically on an analysis of economic growth in post-communist countries. Because the standard neoclassical growth model, based on capital and labor, deals with growth in the long-run, the studies of a decade long post-communist economic development treat economic reform policy, inflation, war, regional variables, and initial conditions as the main independent variables.

Cross-national regression studies conclude that policy of economic liberalization affects positively and significantly growth in postcommunist countries (Denizer, 1997, Hernandez-Cata, 1997, Christoffersen and Doyle, 1998, and Havrylyshyn, Izvorksi, and van Rooden, 1998). Fischer, et al (1996, 61-62) found that economic liberalization policy and macroeconomic stability were positively associated with growth in pooled cross-section and time-series of 25 post-communist countries in 1992-1995. Selowsky and Martin (1997, 350-351) note that the effect of economic reform policy on output becomes positive with a time lag.

Cross-national studies find a negative relationship between growth and inflation in post-communist countries. These studies differ on whether or not to treat inflation as the independent variable in the growth regressions. Denizer (1997) does not include inflation in growth regressions. Aslund, Boone, and Johnson (1996, 237) produce regressions which include economic liberalization index and exclude inflation and vice versa. Christoffersen and Doyle (1998) and Hernandez-Cata (1997), include the log of inflation in their growth regressions.

Many cross-national studies of post-communist economic development include initial condition variables. Blanchard and Kremer (1997) argue that specialization of production was higher in the Soviet Union than in Central European countries. They attribute the output decline to the disorganization of bargaining between suppliers and buyers that was the result of the collapse of central planning and market imperfections such as incomplete contracts and assymetric information. Rose $(1998,26)$ attributes greater reliance on bribes and family or friends based connections in Russia and Ukraine compared to the Czech Republic to the longer legacy of communist rule. De Melo, Denizer, Gelb, and Tenev (1997) find that a cluster of initial conditions, consisting of the initial GDP per capita, urbanization, and industrialization levels, is negatively associated with growth. Fischer et al (1996, 62) reports that trade dependency and the GDP measured at purchasing power parity per capita before the fall of communism are associated negatively with the growth in post-communist countries. In other 
words, initially less developed countries, keeping other variables constant, tend to grow faster than more developed countries. However, Berg, Borensztein, Sahay, and Zettelmeyer (1999) find that the effect of initial economic conditions on growth in 26 post-communist countries is small compared to the role of macroeconomic stabilzation and economic reform.

A number of cross-national studies include corruption in their analysis. Most of these studies suggest that corruption and growth are negatively associated (See Tanzi, 1998). La Porta, et al. (1999, 256) find that latitude and the level of economic development are the best predictors of corruption. Brunetti, Kisunko, and Weder (1997) find that corruption negatively impacted growth in 20 post-communist countries in 1993-1995. However, the significance of this impact varies with different specifications of the growth model.

Some economists argue that post-communist countries with abundant natural resources grow slower than countries that lack significant natural resources. Abundance of natural resources induces rent-seeking and corruption and reduces growth (Leite and Weidmann, 1999). In "Dutch disease" models, the presence or emergence of a large natural resource sector in the economy adversely affects long run growth by shifting production away from a positive externality generating manufacturing sector (Sachs and Warner, 1997). Both of these studies found that natural resource abundance negatively affected growth in a sample of about 70 non-communist countries in 1970-1990.

Aslund, et al. (1996), Stuart and Panayotopoulous (1999), and Hernandez-Cata (1997) introduced regional dummies for the countries of the former Soviet Union, and Eastern and Central Europe into their growth regressions. The inclusion of geographical dummies tends to increase the explanatory power of the regressions. Stuart and Panayotopoulous $(1999,277)$ find that the effects of the Soviet Union and Yugoslavia dummy and inflation on real GDP decline in 1991-1998 are highly significant; while initial condition variables, namely, per capita GDP, industry share, share of trade with market economies, and monetary overhang, are statisically insignificant. The problem is that these regional and geographic variables are created ad hoc and lack theoretical foundations.

Post-communist development is often described as a triple transition, because post-communist countries simultaneously face economic, political, and ethnic changes. Cross-national studies of economic growth include a war variable to capture effects of political and ethnic factors. War and armed conflicts are negatively associated with growth in postcommunist countries. However, statistical significance of the war dummy varies from highly significant to insignificant depending on spe- 
cifications of regression models (Christoffersen and Doyle, 1998, Hernandez-Cata, 1997, Aslund, et al., 1996).

Several recent studies include ethnic and linguistic fragmentation in the analyses of the economic development (La Porta, et al., 1999, Lian and Oneal, 1997, Fedderke and Klitgaard, 1998), La Porta, et al. (1999) found that ethnolinguistically heterogeneous countries exhibit inferior government performance. Gellner (1997) maintains in his theory that nationalism and the nation state emerged because of the modernization needs. Ethnic and linguistic homogeneity facilitates economic modernization, mass education, and governance by reducing transaction costs and inter-ethnic conflicts and providing legitimacy for the nation-state. The Holocaust during World War II and post-war ethnic cleansings turned Central European states, such as Poland and Hungary, into ethnically and linguistically homogenous countries. The existence of communist regimes delayed creation of nation-states in the countries of the former Yugoslavia, Czechoslovakia and the Soviet Union until the 1990s. Therefore, many scholars attribute war and armed conflicts in the former Yugoslavia and the Soviet Union to ethnic factors (See, for example, Bremmer and Taras, 1997).

The reviewed studies imply that economic growth would accelerate as soon as, or shortly after, economic reforms and macroeconomic stabilization are implemented (See, for example, Fisher, et. al., 1996, 64). However, forecasts, made by the World Bank, PlanEcon, the United Nations Economic and Social Council, and other organizations, did not anticipate the significant variation of growth rates in post-communist countries.

As Table 2 shows, PlanEcon forecast positive growth in $1995^{-1997}$ in all post-communist countries it surveyed in 1993. However, according to the IMF (1999a) data, 8 out of 22 countries recorded negative growth in that period. Bulgaria, Russia, Ukraine, Moldova, Azerbaijan, Kazakhstan, Tajikistan, and Turkmenistan are the countries with the widest disparities between forecast and actual growth rates. This forecast employed neoclassical macroeconomic models and used patterns of development (rapid liberalisers, slow reformers, and those affected by war) in other Eastern and Central European countries to extrapolate growth in analogus countries of the former Soviet Republics (EBRD, 1993, 108-109).

The World Bank forecast one-percent annual growth in the former Soviet Republics in 1994-1997 (EBRD, 1993, 108-109). The actual annual growth rate in the former Soviet Republics, excluding three Baltic States, was minus 5.4 percent during this time period (EBRD, 1999, 6). Selowsky and Martin (1997) used their regression of the growth in post-communist countries to simulate growth in Russia, the 
TABLE 2: Forecast and actual growth rates in 1995-1997

\begin{tabular}{llr}
\hline Country & $\begin{array}{l}\text { Forecast GNP growth } \\
\text { (percentages per annum), } \\
\text { PlanEcon }\end{array}$ & $\begin{array}{c}\text { Actiual GDP growth, } \\
\text { (percentages per annum) } \\
\text { IMF }\end{array}$ \\
\hline Bulgaria & $4 \cdot 7$ & $-5 \cdot 2$ \\
Czech Republic & $5 \cdot 6$ & $3 \cdot 8$ \\
Hungary & $5 \cdot 8$ & $2 \cdot 5$ \\
Poland & $4 \cdot 2$ & 6.7 \\
Romania & $3 \cdot 8$ & 1.4 \\
Slovakia & $5 \cdot 0$ & 6.7 \\
Slovenia & $5 \cdot 6$ & $3 \cdot 7$ \\
Estonia & 6.8 & 6.6 \\
Latvia & $5 \cdot 4$ & $3 \cdot 4$ \\
Lithuania & $4 \cdot 3$ & $4 \cdot 7$ \\
Armenia & 8.2 & $5 \cdot 3$ \\
Azerbaijan & $4 \cdot 7$ & -1.6 \\
Belarus & $1 \cdot 7$ & 1.3 \\
Georgia & $5 \cdot 3$ & 8.0 \\
Kazakhstan & 6.5 & -2.0 \\
Kyrgyzstan & $3 \cdot 3$ & $3 \cdot 9$ \\
Moldova & $3 \cdot 8$ & -2.6 \\
Russia & $3 \cdot 5$ & -2.3 \\
Tajikistan & 2.7 & $-5 \cdot 1$ \\
Turkmenistan & $4 \cdot 5$ & $-13 \cdot 9$ \\
Ukraine & 1.5 & -8.4 \\
Uzbekistan & 2.2 & 1.0 \\
\hline Correlation & &
\end{tabular}

Correlation coefficient .41

Sources: EBRD (1993, 111), and IMF (1999a).

largest post-communist economy. They predicted that output growth in Russia would converge to 2 percent per annum in 1997-1999 under stagnant reforms. The actual output in Russia grew by .8 percent in 1997 and declined by 4.6 percent in 1998 (EBRD, 199, 67). The IMF (1999b) expects that the real GDP in Russia will remain unchanged in 1999 .

The reviewed literature on economic growth shows that postcommunist countries with more reformist policies of economic liberalization, low inflation, and no war involvement tend to grow faster than countries with less reformist policies, higher inflation, and war involvement. The question is why political leaders and the population of these countries do not utilize the potential economic gains by adopting the same economic policies carried out in the first group of countries. The logic of economics, as applied to politics, implies that potential economic gains remain unrealized in the second group of countries.

Studies of post-communist economic development rarely attempt to quantify the role of culture (See Raiser, 1997). This paper introduces culture into a statistical analysis of economic growth in post-communist 
countries. Culture includes several elements pertaining to values and traditions shared by individuals: religious and business ethics, social capital, trust, civil society, historical experience and values. Many of these aspects of culture are inter-related. Socialization in a family and community and religion transmits culture from one generation to another. In addition to culture, other factors such as education, age, and personal experience, influence individuals' attitudes and behaviour (Brehm and Rahn, 1997).

Weber $\left(195^{8)}\right.$ argued that Protestant ethic fostered entrepreneurship and led to the rapid growth of capitalism in the West. Weber contrasted the Protestant ethic which emerged during the Reformation with the ethics of medieval Catholicism. Significant changes in Catholic culture occurred by the end of the second half of the 2oth century, and differences between Catholic and Protestant societies have become much smaller than previously (Fukuyama, 1995, 40-41). Religious doctrine and ethics of Catholicism have become less hostile to capitalism than in the past (Novak, 1993). Huntington (1996) includes both Protestant and Catholic countries, except those located in Latin America, Africa, and East Asia, in his definition of Western cultural civilization. In contrast to the Orthodox, Muslim, Buddhist and other civilizations, Western civilization is characterized by individualism, the rule of law, and representative democracy.

Lal $\left(1998,95^{-97}\right)$ argues in his study of the role religion in the economic development that the Orthodox ethic differs from the ethics of Western Christianity. In contrast to the Latin branch of Christianity which separated Papal authority from the authority of a king, the Eastern branch did not draw a clear line between the Orthodox Christianity and the ruler. The Orthodox Church provided religious foundations for an autocratic Russian State and helped to isolate Russia from the influence of Catholic and Protestant Europe.

Social capital, or trust, refers to individuals' ability, which arises from commonly shared values, to cooperate in groups and organizations (See Coleman, 1988). ${ }^{3}$ Trust in other people helps to extend economic exchange beyond a circle of family members and friends and promote growth of large business enterprises by reducing uncertainty and opportunistic behaviour (Fukuyama, 1995, Raiser, 1999).

Trust in family and friends can increase economic output under certain conditions, but it also leads to nepotism and corruption. Some scholars argue that family centered Confucian ethics provided a foundation for growth of small enterprises in China, Taiwan, Hong Kong, Singapore, and some other East Asian countries and contributed to their economic growth when the government adopted policies of economic liberalization and there was a shift from a Fordist to more flex- 
ible production model (See Whyte, 1996). At the same time, it inhibited growth of large non-family run businesses (Fukuyama, 1995, 6995). Lipset and Lenz (2000) link familism and religious ethics to corruption. They found in their cross-country analysis of the 1990-1993 World Values Survey that stronger familism expressed by "unqualified respect and love for parents" increased corruption. Protestant countries were less familistic than Catholic countries. Countries with a high proportion of Protestants in the population were less corrupt than Catholic countries, but both these groups of countries appeared to be less corrupt than countries with a high proportion of people who adhered to other religions.

The concept of social capital or trust is closely related to the concept of civic society (See Brehm and Rahn, 1997). Civil society refers to a network of associations and organizations which are not state-based or family-based. Trust in strangers enables individuals to successfully solve collective action problems and form such associations. In this sense, one can view private businesses as a part of civil society (Fukuyama, 1995, 4-5).

Divergent historical experience is another source of cultural differences. Putnam $(1993,121-137)$ traces the roots of differences in institutional performance of Italian regions to the patterns of governance prevalent in the North and South during medieval times. Communal republics in the North developed a network of civic and business associations and a system of commercial law. In contrast, the Norman kingdom in the South practiced an autocratic form of governance, and family ties became of greater importance than inter-personal trust and civil society.

North (1990, 101-103, 114-117) emphasizes the role of colonial experience in introducing the rule of law. The U.S. Constitution reflected the colonial heritage of Britain, which had a strong tradition of the rule of law. In contrast, Spain and Portugal instituted a system based on authoritarianism and clientelism in their Latin American colonies. After gaining their independence, many Latin American countries adopted constitutions based on the U.S. Constitution. However, the mechanisms of the rule of law enforcement and values and behaviour of the actors in these countries continue to differ from those in the United States.

One can find similar differences among the Austro-Hungarian Empire, Prussia, the Russian Empire and the Ottoman Empire (Landes, 1998, 238-242, 396-402). The Habsburg Monarchy issued laws which limited serfdom at the end of the 18th century and then completely abolished it in 1848 . Serfdom was abolished in Prussia in 1809. In contrast, the Russian Tsar abolished serfdom in $1861 .{ }^{4}$ 
Emancipation of peasants occurred in Romania in 1864 and Bulgaria in 1880 at the time when they gained autonomy from the Ottoman Empire. Even though constitutions were more limited in the AustroHungarian Empire and the German Empire than in the U.S., they were introduced earlier than in the Russian Empire and the Ottoman Empire.

Culture can affect economic growth both directly and indirectly. Fukuyama (1995) argues that trust, or social capital, positively affects growth and helps to explain the growth residual not explained by neoclassical models. Landes (1998) identifies culture as one of the main factors of economic development. Culture also affects economic growth indirectly by affecting reform policy and chances of war or armed conflict. Democracy requires supportive culture (Lipset et. al., 1993). Huntington (1996) develops a causal connection between culture and war. He argues that the clash of civilizations manifests itself in international and regional conflicts in the period after the Cold War.

Comparable cross-national measures of culture are much less developed than measures of economic development. The World Bank, IMF, United Nations, and EBRD, which collect and publish data on economic, and to a lesser extent, social and environmental development, do not report similar data on strength of civil associations, religious composition of the population, or other indicators of political and economic culture.

Most cross-national studies, which examine the effects of culture on economic performance, use aggregate survey data to quantify culture (See Knack, 1999). These studies found that culture, operationalised as trust and achievement motivation, positively affects economic growth and government efficiency (Granato, et al., 1996, Knack and Keefer, 1997, La Porta, Lopez-de-Silanes, Shleifer and Vishny, 1997). However, the cultural measures, which are aggregated from survey data, encounter a number of methodological and theoretical problems. Even World Values Surveys, which ask the same questions in different countries, face comparability problems which arise because of differences in language, quality and timing of surveys, and representativeness of their samples (Silver and Dowley, 1997). Surveys might reflect not only deeply held cultural values but also current attitudes which depend on changing economic and political conditions (Lipset, 1996, 24-25). Culture is traditionally defined and studied by means of "thick description," e.g., ethnographical and historical research and case studies (See Lavoie and Chamlee-Wright, 1999, and Fukuyama, 1995, 33-38).

Cross-national surveys find that attitudes expressed by respondents from post-communist countries are generally not consistent with descriptive and historical studies of political and economic culture. The 
former report that, contrary to the conclusions of the latter, people in countries of the former Soviet Union do not differ significantly in their attitudes towards democracy, free market, and expressions of trust when compared to people from Central European countries and even in some cases in comparison to people from the United States and other Western countries (See Miller, White and Heywood, 1998, Miller, Hesli, and Reisinger, 1994, Reisinger, Miller, and Hesli, 1995, Shiller, Boyko, and Korobov, 1991).

The analysis of the New Democracies Barometer and New Russia Barometer, which includes 9 post-communist European countries, showed that intra-country variations in the level of trust were larger than between-country variations (Mishler and Rose, forthcoming). Silver and Dowley (1997) found that within-country differences on questions concerning trust and achievement motivation in multi-ethnic societies, including post-communist ones, were often larger than between-country differences.

Studies which analyze individual level survey data from countries with different cultural traditions are not subjected to the compatibility problems to the same degree as cross-national studies. A survey of local governments in Poland found that local government performance was most strongly affected by their historical location. A Northern and Western part of Poland which belonged to Germany until World War II demonstrated the best performance. Next was the region which was a part of the German Empire before World War I. It was followed by the former Austrian region. The region which was a part of the Russian Empire exhibited the weakest performance. (See Gorzelak, 1998, 124-126).

Surveys of public opinion in Ukraine show that respondents from Western Ukraine, especially Greek Catholics, and respondents from regions which belonged to the Austro-Hungarian Empire before World War I, differ considerably in their political attitudes from Eastern Ukrainians (Wilson and Birch, 1999, Barrington, 1997). Procommunist attitudes are much stronger in Eastern Ukraine than in more nationalist Western Ukraine. However, there is some evidence that differences in civil society development between Western and Eastern Ukraine are not as significant as their political differences. (See O'Loughlin and Bell, 1999). ${ }^{5}$

\section{Methodology and data}

This paper employs cross-national regression analysis to determine the influence of culture on the economic growth in post-communist countries. The most important differences from existing studies of economic growth are the following: updated data, the increased number of coun- 
tries analyzed, and the path analysis, or structural equation modeling.

In contrast to previous cross-national studies of growth in postcommunist countries, Bosnia and Yugoslavia (Serbia and Montenegro) are included in the analysis. The inclusion of these two countries makes the results of the study representative of all post-communist countries. GDP, price level, and initial economic conditions in Bosnia and Yugoslavia are estimated from the EBRD, IMF, World Bank, and UNECE reports as well as the Economist Intelligence Unit (EIU 1999, 1998) surveys of these countries.

The paper employs a path model, also called a structural equation model, to estimate both direct and indirect effects of independent variables on the dependent variable. ${ }^{6}$ Ordinary least squares regressions are used to estimate direct effects. Indirect effects are calculated by multiplying standardized path coefficients. The ratio of the real GDP in $1998 / 1989$ is the primary dependent variable. The economic reform index, log of price level, corruption index, and the war dummy are the intermediate variables. Initial economic condition variables, cultural variables, and ethnic composition of the population before the collapse of communism are the main exogenous variables. The model also analyzes an interaction between natural resources, latitude, and variables included in the path model. (See Figure 2).

The economic reform idex estimated by the Freedom House for 28 post-communist countries, quantifies the extent of the economic reforms as of March 1998 (Karatnycky, Motyl, and Graybow, 1998). It was reversed to assign 7 to the most advanced reforms and 1 to the least advanced reforms (Table 1 ). The economic liberalization index derived from the EBRD estimates is highly correlated with the Freedom House reform index but the former does not include Bosnia, Yugoslavia and Mongolia. ${ }^{7}$ Many post-communist countries experienced hyperinflation, and differences in the 1998/1989 price levels are exceptionally high. Log of price level is used in the regressions as a proxy for policy of macrostabilization.

The Freedom House estimates the extent of corruption in all postcommunist countries. The index of corruption, used in the paper, is derived from the estimate. The 1998 Freedom House index is highly correlated with the Transparency International (1999) corruption perceptions index, but the latter did not cover all post-communist countries.

The war dummy assigns 1 to war torn countries and o to all other countries. Russia and Slovenia are not classified as war torn countries. The war in Chechnya in 1994-1996 was confined to a relatively small region. The war in Slovenia lasted 10 days in 1991 and had low intensity. The ethnicity variable indicates the proportion of ethnic minorities in post-communist countries before 1990. It is derived from the 1989 Soviet census (Bremmer and Taras, 1997) and CIA (1992). 
Initial condition variables are derived from De Melo, et al. (1996). The 1989 GDP per capita, measured in purchasing power parity in U.S. dollars, seves as the proxy for the initial level of economic development. Share of industry in GDP in 1990 represents the structure of the economy. ${ }^{8}$ The ratio between the average of exports and imports and GDP in 1990 measures trade dependence. Percent change in real wage less the percent change in real GDP in 1987-1990 serves as an indicator of repressed inflation. The number of years under central planning denotes the legacy of communist rule.

Several cultural variables are used to identify different aspects of culture: proportion of Catholics and Protestants in the population, civil society index, business ethics index, historical experience dummy, and proportion to those who say that most people can be trusted. To make the analysis more reliable, the culture index is derived from these variables.

In contrast to Fish $(1998,39-42)$, who uses a dummy variable to distinguish between Western Christianity and other religions, this study employs the proportion of Catholics and Protestants in the population. Catholics and Protestants constitute the majority of the population in Croatia, Czech Republic, Hungary, Poland, Slovakia, Slovenia, Estonia, Latvia, and Lithuania (see Table 1). Estonia is the only predominantly Protestant country among post-communist countries. Proportions of Protestants and Catholics are similar in Latvia. However, there are significant Orthodox Christian minorities in Estonia and Latvia. The rest of the countries are predominantly Orthodox Christian (Armenia, Belarus, Bulgaria, Georgia, Macedonia, Moldova, Romania, Russia, Ukraine, and Yugoslavia), Muslim (Albania, Azerbaijan, Kyrgyzstan, Tajikistan, Turkmenistan, and Uzbekistan) or Buddhist (Mongolia). Proportions of Muslims in Bosnia and Herzegovina, and Kazakhstan are slightly higher than the proportions of Orthodox Christians. The data on religious affiliation of the population are estimates obtained from various sources, including CIA (1997), Worldmark Encyclopedia (1995), and individual country studies. These sources sometimes give approximate and slightly different numbers on religious affiliation.

The Catholic-Protestant variable is intended to capture not only the current religious beliefs, but also the influence of parents' and grandparents' economic and political values which were religiously-based. Generations born under communism, which severely limited religious expression, were much more highly educated than their parents and did not necessarily absorb these values in the form of religious beliefs. Rose, Mishler, Haerpfer $(1998,184-185)$ found that approximately half of the respondents in the nine post-communist countries surveyed rarely or never go to church. 
On the basis of the country studies, Freedom House experts estimate the strength of the civil society, a part of the democratization index. (Karatnycky, et al., 1998). The civil society index, derived from these estimates, reflects the number, membership, organizational capacity and financial independence of nongovernmental, charitable, nonprofit organizations, free trade unions, and business associations, as well as their public perception and the legal environment they operated in as of March 1998. The Wall Street Journal's Central European Review board of economists estimated the business ethics index for all postcommunist countries, except Mongolia, in the Fall of 1999 (See Shiskin, 1999). A potential problem with the 1998 civil society index and the 1999 business ethics index is that they may reflect not only cultural influences but also results of the reform policy.

Historical experience dummy, a crude measure of the imperial legacy, indicates whether the main part of the country belonged to the Austro-Hungarian Empire and Germany (1), or the Russian Empire, the Ottoman Empire, and China (o) during the 19th or the beginning of the 2oth century. The Austro-Hungarian Empire included present day Hungary, Czech Republic, Slovakia, Slovenia, Croatia, and small parts of Poland, Ukraine, Romania, and Serbia until World War I. Western and Northern regions of Poland belonged to Prussia which later became a part of Germany. The Ottoman Empire controlled Bulgaria, Romania, most of Serbia, which became independent by the end of the 19th century, Bosnia and Herzegovina, which was administered by the Astro-Hungarian Empire since 1878 and annexed in 1908, and Albania and Macedonia until the beginning of the 2oth century.

The Russian Empire, which included Estonia, Latvia, Lithuania, Belarus, most of Ukraine, and the Transdniestria region of Moldova since the 18 th century, incorporated Armenia, Azerbaijan, Georgia and most of Moldova, and also colonized the nomadic, semi-nomadic, and mountain people and their state formations in Central Asia in the 19th century. Mongolia, mostly populated by nomads, was loosely controlled until 1912 by the autocratic Ch'ing Empire, which ruled China (Barraclough, 1998, 214-217, 228-232).

The proportion of respondents who said that most people can be trusted is derived from the $1900-1993$ and $1995^{-1997}$ World Values Surveys. The aggregated survey data are available for 19 postcommunist countries. My analysis shows that correlations between the trust variable and the other cultural variables used in this paper are extremely weak and not always in the expected direction. These correlations range from -.15 for the business ethics index to .04 for the historical experience dummy. In contrast, the civil society index, the business ethics index, the proportion of Catholics and Protestants, and 
historical experience dummy are positively and highly inter-correlated. The lowest correlation, .62, is between the civil society index and the historical experience dummy. The business ethics variable has the highest correlation, .84 , with the religious variable and civil society variable.

The factor analysis confirms these findings by identifying one factor consisting of the civil society index, the proportion of Catholics and Protestants, the historical experience dummy, and the business ethics index. An index derived from these variables, excluding the business ethics index which is not available for all countries, has a high reliability coefficient, .88. This index denotes Western cultural traditions on a scale from o to 10 .

\section{Regression Analysis}

As Figure 1 shows, economic reform policy is positively associated with growth in a bivariate regression. Correlation between these two variables is .48. However, there is a visible pattern in the regression plot. Poland, Slovenia, Czech Republic, Hungary and Estonia, countries with mostly Western cultural traditions achieved both the highest growth levels and the most advanced reforms. In contrast, Belarus, Turkmenistan, Bosnia, Tajikistan, Macedonia, Yugoslavia, Azerbaijan, and Ukraine, countries with mostly non-Western cultural traditions, are in the opposite corner. They have the lowest growth levels and the least advanced economic reforms.

Table 3 shows the effect of the inclusion of the culture variable in growth regressions. In different specifications of regressions, which omit the cultural variable, repressed inflation tends to be the most significant variable among initial economic condition variables. ${ }^{9}$ Number of years under communist rule, industrial share of GDP, and trade dependency do not have significant effects on growth and are not included in the path analysis. Corruption, proportion of ethnic minorities, and war negatively affect growth, but only the last two variables are statistically significant. ${ }^{10}$ (See regression I and II in Table 3).

In regression I, the economic reform has a positive but statistically insignificant effect on growth. Log of price level is significantly and negatively associated with growth in post-communist countries (regression II, Table 3). The statistical analysis supports a view that inflation is closely linked to the government economic policy (Temple, 1999, p. 145). Correlation between the log of cummulative inflation and the economic reform index is .78. In this sense, inflation serves as a proxy for the policy of macroeconomic stabilization in post-communist countries. For these reasons, the effect of inflation on growth is estimated separately from the effect of economic reform on growth. 


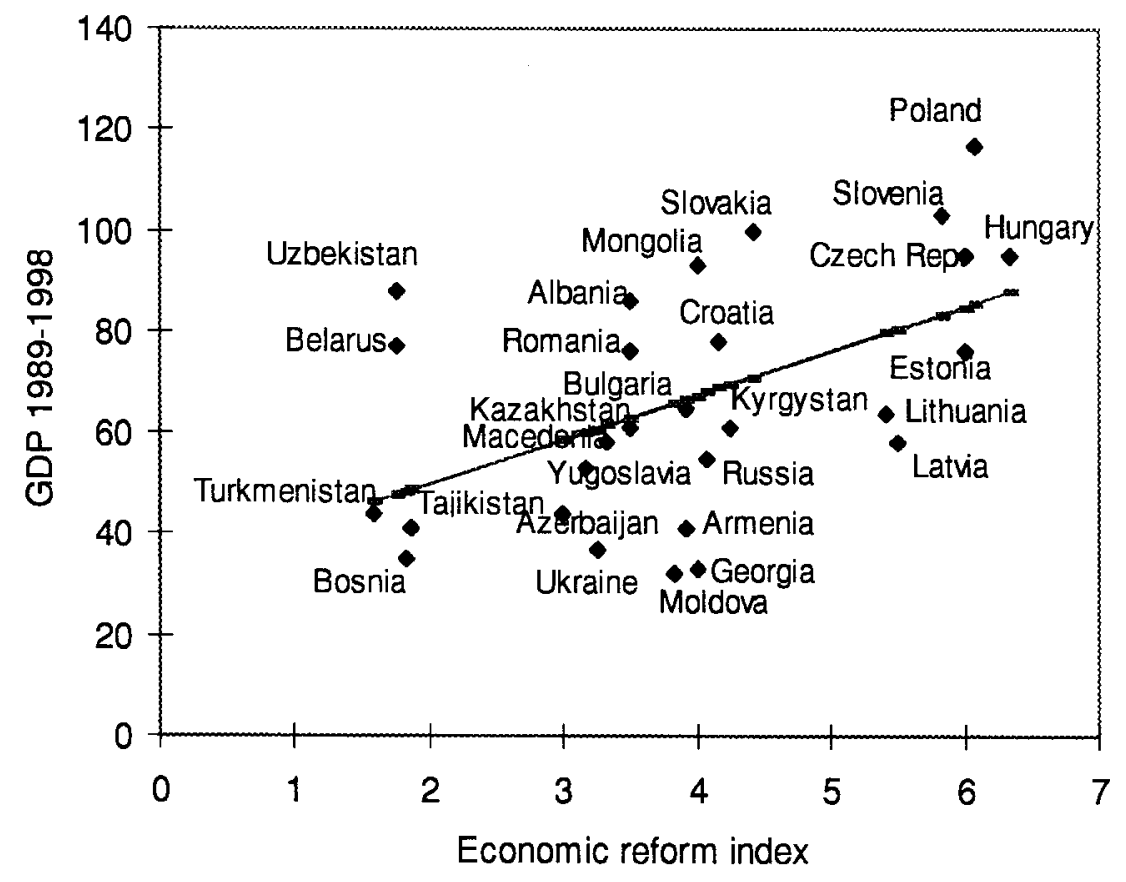

FIGURE 1: Regression plot of GDP growth in I990-I998 and economic reform index.

Inclusion of the culture variable in the growth regressions III and IV increases their explanatory power. Adjusted R square increases from .62 and .67 to .69 and .71 . The Western culture index becomes the strongest direct determinant of growth in post-communist countries. In both regression specifications, culture has the highest standardized (beta) coefficients, .67 and .49 and is statistically significant. Keeping other variables constant, the increase of the Western culture index by 1 unit on a scale from o to 10 increases growth level in 1998 compared to 1989 by about 4 or 5 percentages points depending on regression specification, (Table 3 ).

The multicollinearity problem makes it difficult to distinguish the influence of different aspects of culture on economic growth. The civil society index and the business ethics index are highly correlated with the economic reform $(.96$ and .86$) .{ }^{11}$ The path models, which use the religion variable or historical experience dummy to represent culture, produce results similar to those produced by the Western culture index.

The effect of inflation on growth remains negative and statistically significant at the 10 percent level. The effect of the 1998 economic 
reform index on growth becomes slightly negative. However, its substitution by the 1995 economic liberalization index makes the effect of reform on growth positive again. This suggests the presence of a lag between economic reform and growth. ${ }^{12}$ Substitution of the log of the $1998 / 1989$ price level by log of the 1997/1989 price level preserves the significance of this variable. The Western culture index and the war dummy remain statistically significant in the lagged growth regressions.

The war dummy still has a significant negative effect on growth even when the culture variable is included in the regression. The average war-torn country has, depending on a specification of the regression, 18 or 21 percentage points lower growth level than the average country which did not experience a war. The negative effect of the initial level of economic development (GDP per capita) on growth increases and becomes statistically significant. In other words countries which were poorer in 1989 tend to grow faster than richer countries keeping the other factors constant. Standardized coefficients for proportion of ethnic minorities and repressed inflation decrease but remain negative. Substitution of the other initial condition variables for repressed inflation does not make them significant but makes the effect of culture on growth even stronger.

Natural resource abundance, measured as crop land per capita in 1993 and primary energy production per capita in 1992, correlates negatively with economic growth, but the correlations are weak, -.05 and $-.11 .{ }^{13}$ Correlations of the land and energy variables with corruption (.07 and .23) and economic reform index (.10 and .01) are also weak. The natural resource variables are not statistically significant in the growth regressions and are not included in the path models. A similar relationship exists between growth and latitude. Latitude has a positive but weak (.25) correlation with growth. This variable is not significant in the multivariate regressions. Latitude is excluded from the path analysis because of its weak explanatory power and weak theoretical foundations.

The path (structural equation) model allows us to estimate both direct and indirect effects of exogenous and intermediate variables on growth. Figure 2 shows the path model which includes economic reform, war, and corruption as intermediate variables, and the initial GDP per capita, repressed inflation, Western culture index and ethnicity as exogenous variables. The regression III estimates the direct effects (Table 3). Indirect effect are estimated from separate regressions for which arrows indicate dependent and independent variables.

As Figure 2 shows, the Western culture index has a highly significant $(p<.01)$ and positive effect on economic reforms. However, because the 
TABle 3: Direct determinants of economic growth in post-communist countries

\begin{tabular}{|c|c|c|c|c|}
\hline & I & II & III & IV \\
\hline & $\begin{array}{l}\text { Standardized } \\
\text { coefficient }\end{array}$ & $\begin{array}{l}\text { Standardized } \\
\text { coefficient }\end{array}$ & $\begin{array}{l}\text { Standardized } \\
\text { coefficient }\end{array}$ & $\begin{array}{l}\text { Standardized } \\
\text { coefficient }\end{array}$ \\
\hline GDP per capita 1989 & $\begin{array}{l}-.15 \\
(-.001)\end{array}$ & $\begin{array}{l}-.13 \\
(-.001)\end{array}$ & $\begin{array}{l}-.29^{*} \\
(-.003)\end{array}$ & $\begin{array}{l}-.27^{*} \\
(-.003)\end{array}$ \\
\hline Repressed inflation & $\begin{array}{l}-.34^{* *} \\
(-.75)\end{array}$ & $\begin{array}{l}-.22 \\
(-.49)\end{array}$ & $\begin{array}{l}-.14 \\
(-.31)\end{array}$ & $\begin{array}{l}-.10 \\
(-.22)\end{array}$ \\
\hline Economic reform index & $\begin{array}{l}.06 \\
(1.06)\end{array}$ & & $\begin{array}{l}-.12 \\
(-2.10)\end{array}$ & \\
\hline Log of price level & & $\begin{array}{l}-.33^{*} \\
(-1.81)\end{array}$ & & $\begin{array}{l}-.22 * \\
(-1.24)\end{array}$ \\
\hline Corruption & $\begin{array}{l}-.25 \\
(-6.03)\end{array}$ & $\begin{array}{l}-.19 \\
(-4.55)\end{array}$ & $\begin{array}{l}-.01 \\
(-.13)\end{array}$ & $\begin{array}{l}.03 \\
(.82)\end{array}$ \\
\hline Ethnicity & $\begin{array}{l}-.28^{*} \\
\left(-.4^{1}\right)\end{array}$ & $\begin{array}{l}-.20^{*} \\
(-.30)\end{array}$ & $\begin{array}{l}-.22^{*} \\
(-.33)\end{array}$ & $\begin{array}{l}-.17 \\
(-.25)\end{array}$ \\
\hline War & $\begin{array}{l}-.3^{8 * * *} \\
(-19 \cdot 31)\end{array}$ & $\begin{array}{l}-.31 * * \\
(-15.8)\end{array}$ & $\begin{array}{l}-.42^{* * * *} \\
(-21.44)\end{array}$ & $\begin{array}{l}-.36^{* * * *} \\
(-18.39)\end{array}$ \\
\hline Western culture index & & & $\begin{array}{l}.67^{* *} \\
(5 \cdot 29)\end{array}$ & $\begin{array}{l}.49^{*} \\
(3.89)\end{array}$ \\
\hline \multirow{3}{*}{$\begin{array}{l}\text { Constant } \\
\text { Adjusted R-squared } \\
\text { N }\end{array}$} & $(119.22)^{* * * *}$ & $(123 \cdot 48) * * *$ & $(95 \cdot 30)^{* * *}$ & $\left(93 \cdot 3^{1}\right)^{* * *}$ \\
\hline & .62 & .67 & .69 & $\begin{array}{l}.71 \\
28\end{array}$ \\
\hline & 28 & 28 & 28 & \\
\hline
\end{tabular}

Note: Unstandardized coefficients appear in parentheses.

*Significant at .10;** significant at .05; *** significant at .01.

immediate effect of the economic reform on growth is slightly negative, the indirect effect of culture on growth is also slightly negative. It becomes positive, but statistically insignificant, when the 1995 index of reform is used. Culture is the leading determinant of corruption. The Western culture index is negatively associated with corruption. ${ }^{14}$ In the corruption regression, Beta coefficient for culture (-.71) is much higher than for the other variables and is statistically significant $(\mathrm{p}<.05)$. The Western culture index and initial GDP per capita are negatively associated with war, but the results are not statistically significant. The proportion of ethnic minorities in the population has a slight positive, but statistically insignificant, effect on war and armed conflicts. ${ }^{15}$ (See Table 4). This result does not lend support to the proposition that wars and armed conflicts are the result of the ethic fragmentation of the population.

The substitution of the price level log for the economic reform index in the path (structural equation) model makes the total indirect effect of culture on growth the largest (.11) compared to other variables (Table 4). Culture is the strongest determinant of the cumulative inflation variable. The Western culture index has a negative and statistically significant effect on the log of the 1998/1989 price level $(\mathrm{p}<.05)$. 


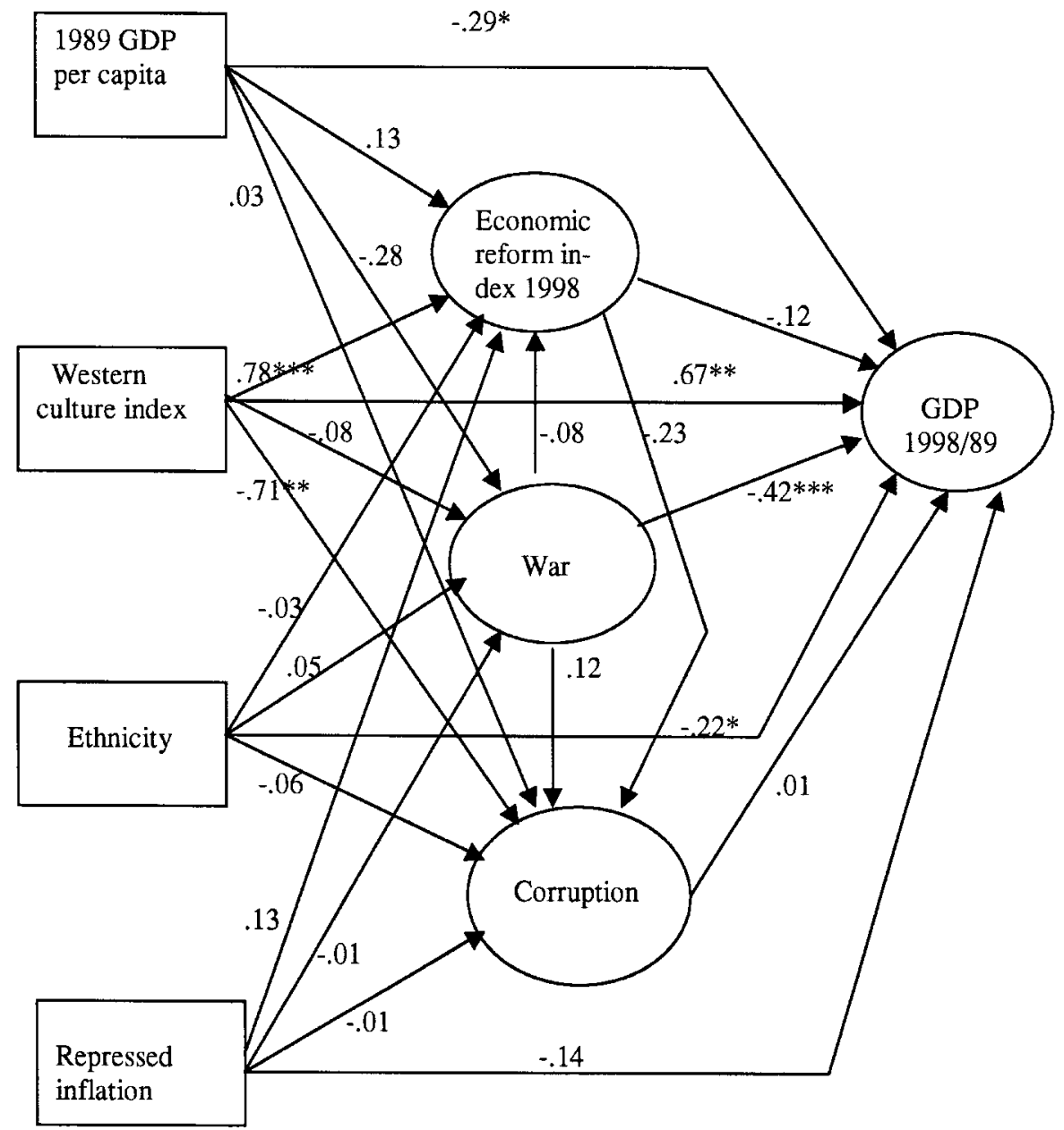

Note: * significant at .Io; ** significant at .o5; *** significant at .o I.

FIGURE 2: Path (structural equation) model of growth in post-communist countries.

Total effects are almost identical in both specifications of the path model. Compared to other variables, culture has the largest total effect on growth in post-communist countries. An increase of the Western culture index by 1 unit on a scale from o to 10 makes the $1998 / 1989$ growth index higher by .60 or .62 standard deviations depending on the path model specification.

The sensitivity analysis shows that Uzbekistan, Belarus and Ukraine are outliers in regressions III and IV. Uzbekistan and Belarus have the largest positive residuals; while Ukraine has the largest negative 
TABLE 4: Direct and indirect determinants of growth, standardized coefficients

\begin{tabular}{|c|c|c|c|c|c|c|}
\hline & \multicolumn{3}{|c|}{ Path model I } & \multicolumn{3}{|c|}{ Path model II } \\
\hline & $\begin{array}{l}\text { Direct } \\
\text { effect }\end{array}$ & $\begin{array}{l}\text { Indirect } \\
\text { effect }\end{array}$ & $\begin{array}{l}\text { Total } \\
\text { effect }\end{array}$ & $\begin{array}{l}\text { Direct } \\
\text { effect }\end{array}$ & $\begin{array}{l}\text { Indirect } \\
\text { effect }\end{array}$ & $\begin{array}{l}\text { Total } \\
\text { effect }\end{array}$ \\
\hline 1989 GDP per capita & -.29 & .10 & -.19 & -.27 & .09 & -.18 \\
\hline Repressed inflation & -.14 & -.01 & -.15 & -.10 & -.05 & -.15 \\
\hline Economic reform index & -.12 & .00 & -.12 & & & \\
\hline Log of price level & & & & -.22 & .01 & -.21 \\
\hline Corruption & -.01 & & -.01 & .03 & & .03 \\
\hline Ethnicity & -.22 & -.02 & -.24 & -.17 & -.07 & -.24 \\
\hline War & -.42 & .01 & $-.4^{1}$ & -.36 & -.05 & $-.4^{1}$ \\
\hline Western culture index & .67 & -.05 & .62 & .49 & .11 & .60 \\
\hline
\end{tabular}

residuals. As mentioned above, output figures in Uzbekistan and Belarus, where the government still dominates the economy, are likely to be inflated. When these two countries-outliers are eliminated from growth regressions, the Western culture index preserves its largest and statisically significant coefficient. The effect of the 1998 economic reform index on growth becomes positive, and the price level log increases considerably in its regression coefficient and statistical significance.

To see whether a specific character of Greek Catholicism is responsible for the overprediction of growth in Ukraine in both regressions, I re-coded the religious variable and adjusted the culture index accordingly. The Ukrainian Greek Catholic Church traces its roots to the end of the 16th century when a number of Orthodox Church leaders in Ukraine accepted the Vatican's jurisdiction, but preserved Eastern Orthodox rites and customs. The Greek Catholic Church in Western Ukraine was forcibly incorporated into the Russian Orthodox Church after World War II, but restored during perestroika. When the adjusted culture index is included in the regressions, Ukraine's negative residuals decrease, but do not completely disappear. ${ }^{16}$

Data on economic growth and inflation could be less reliable in Bosnia, Yugoslavia, and Mongolia than in the other post-communist countries. To check whether this fact affects regression results, I estimated path models without Bosnia, Yugoslavia, and Mongolia. The exclusion of these countries from regressions does not have a strong impact on the path models. Culture has the largest total effect on economic growth in both specifications of the growth model.

\section{Conclusion}

Post-communist countries experienced a significant variation in their levels of economic growth in the 1990s. A growing number of studies 
attempts to explain this variation. The neoclassical growth theory and endogenous growth theory focus on the tole of labor, capital, and technology in long-term economic growth. Empirical studies of growth in cross-sections of countries show that many economic, political and geographic variables are associated with growth.

Cross-national studies find that the policy of economic reform and macroeconomic stabilization have positive effects and war has a negative effect on growth in post-communist countries. However, these studies leave open the question as to why political leaders and voters in countries, which suffered the largest GDP decline, do not choose policies carried out in countries where GDP recovered to the 1989 level.

This paper has tested a hypothesis that culture, defined in terms of civil society, social capital, trust, religious and business ethics, and historical experience, affects the variation of economic growth in postcommunist countries. Keeping other variables constant, countries which have a more Western culture suffered less output decline than countries with less Western culture. The analysis, like most other studies, shows that macroeconomic stabilization policy, operationalized as the $\log$ of price level, has a contemporaneous effect on growth. Although the effect of contemporeneous economic reform on growth is slightly negative, there is an indication that it becomes somewhat positive with several years time lag. The initial GDP per capita, repressed inflation, and proportion of ethnic minorities are negatively associated with economic growth.

A path analysis, or structural equation modeling, supports the cultural hyphothesis. Culture indirectly affects growth by influencing economic reform policy, macroeconomic stabilization, corruption, and war. Culture has the strongest effect on the policy variables and corruption. The combined direct and indirect effect of culture on economic growth in post-communist countries is the largest. This result is not sensitive to outliers and differences in the specification of the model. However, the multicollinearity problem makes it difficult to determine which aspects of culture are the most responsible for the divergence of economic growth in post-communist countries.

\section{NOTES}

1. Barro $(1991,407)$ also argues that faster growth of poor countries does not necessarily lead to income convergence when the level of income in each country is subject to continuous random disturbances.

2. Krugman (1995, viii) notes:

economic geography - the location of activity in space - is a subject of obvious 
practical importance and presumably of considerable intellectual interest. Yet it is almost completely absent from the standard corpus of economic theory.

3. For review of social capital and trust studies from different theoretical and methodological perspectives, see Knack (1999), Foley and Edwards (1999), and Seligman (1997).

4. Serfdom was abolished on most of the present territory of the Baltic States by about half a century earlier.

5. Miller, et al. (1998) attempted to test cultural theories and compare values and attitudes of Western and Eastern Ukrainians. However, their survey in Ukraine was not fully representative of Western Ukraine. In representing Western Ukraine, Miller, et al. (1998, 70-72) selected only one Greek Catholic region out of five, which used to be part of the AustroHungarian Empire, but chose both Orthodox regions, which belonged to the Russian Empire.

6. For statistical methodology of path analysis (structural equation modeling), see Asher (1983).

7. The 1997 economic liberalization index was constructed from eight indicators: large-scale privatization, small-scale privatization, governance and restructuring, price liberalization, trade and foreign exchange system, competition policy, banking reform and interest rate liberalization, and securities markets and non-bank economic institutions. All these indicators are highly intercorrelated. Their factor analysis produces a single factor.

8. Initial economic condition variables for Bosnia and Herzegovina and Yugoslavia are estimated from World Bank publications and national statistics.

9. This includes regressions with all initial condition variables or just one initial condition varaible at a time.

10. Corruption and the economic reform index are highly correlated (.77). However, exclusion of one of these variables from regressions does not make another variable significant.

11. The rule of law indexes derived from Freedom House and the Wall Street Journal estimates, are also highly correlated with the 1998 economic reform index. The same applies to the Freedom House democratization, political freedom, and civil rights indexes. Knack (1999) did not include these measures in the narrow definition of social capital.

12. The 1997 EBRD economic liberalization index and the December 1996 Freedom House economic reform index, which like the 1995 EBRD liberalization index, are available for 25 out of 28 post-communist countries, have a slightly negative, but statistically insignificant, effect on growth. The EBRD liberalization indexes are derived from Aslund, et al. (1996, 221) and EBRD (1997, 14). The Freedom House index is derived from Karatnycky, et al (1997).

13. Crop land per capita in 1903 and primary energy production per capita in 1992 are the earliest available comparable measures of natural resources in the former communist countries (See World Resources (1996, 240-241) and Energy Statistics Yearbook (1995, 16-3o)). These measures in the first post-communist years appear to be similar to those during the last years of communism. The correlation between crop land per capita in 1993 and $198_{3}$ for 21 of these countries is .98. The correlation between energy production in 1992 and 1980 for 23 of these countries is .99. Crop land includes land under temporary and permanent crops, temporary meadows, gardens, and temporarily fallow land. Land data for Armenia and Yugoslavia are for 1994 (World Resources, 1998, 286-287, 290). Energy production is expressed in metric tons of coal equivalent and includes solid, liquid, and gas energy and primary electricity from hydro, nuclear, geothermal and wind sources.

14. A high correlation between the cultural index and corruption (.-83) raises multicollinearity concerns. However, the omission of the cultural index does not make corruption statistically significant in the regressions III and IV. When the corruption index is omitted, culture remains statistically significant.

15. The logistic regression of 1989 GDP per capita, Western culture index, proportion of ethnic minorities, and repressed inflation on the war dummy produced similar results.

16. Ukraine and Uzbekistan also appear among outliers in Berg, et. al. $(1999,41)$.

\section{REFERENCES}

Asher, Herbert (1983) Causal modeling. Second edition. Newbury Park, Ca.: Sage Publications. Aslund, Anders, Peter Boone, and Simon Johnson (1996) How to stabilize: lessons from post-communist countries, Brookings Papers on Economic Activity, 1, 21 7-291.

Barraclough, Geoffrey (Editor) (1998) HarperCollins Atlas of World History. Ann Arbor: Borders Press. 
Barrington, Lowell (1997) The geographic component of mass attitudes in Ukraine, Post-Soviet Geography, 38, 10, 601-614.

Barro, Robert (1991) Economic growth in a cross-section of countries, The Quarterly Journal of Economics, 106, 2, 407-443.

Berg, Andrew, Eduardo Borensztein, Ratna Sahay, and Jeromin Zettelmeyer (1999) The evolution of output in transition economies: Explaining the differences, IMF Working Paper WP/99/ 73.

Blanchard, Oliver and Michael Kremer (1997) Disorganization, Quarterly Journal of Economics, 112 , 4, $1091-1126$

Bloom, David and Jeffrey Sachs (1998) Geography, demography and economic growth in Africa, Brookings Papers on Economic Activity, 2, 207-273.

Brehm, John and Wendy Rahn (1997) Individual-level evidence for the causes and consequences of social capital, American Journal of Political Science, 41, 3, 999-1023.

Bremmer Jan and Ray Taras (ed.) (1997) New states, new politics: Building the post-Soviet nations. Cambridge: Cambridge University Press.

Brunetti, Aymo, Gregory Kisunko, Beatrice Weder (1997) Institutions in transition. Reliability of rules and economic performance in the former socialist countries, World Bank Working Paper.

Christoffersen, Peter and Peter Doyle (1998) From inflation to growth - Eight years of transition, IMF Working Paper WP/g8/ Ioo.

CIA (1992) The world factbook I992. Washington D.C.: Central Intelligence Agency.

CIA (1997) The world factbook I997. Washington, D.C.: Central Intelligence Agency.

Coleman, James (1988) Social capital in the creation of human capital, American Journal of Sociology, Supplement, 94, 95-120.

De Long, Bradford and Lawrence Summers (1991) Equipment investment and economic growth, Quarterly Journal of Economics, 106, 2, 445-502.

De Melo, Martha, Cevdet Denizer, Alan Gelb, and Stoyan Tenev (1997) Circumstance and choice: The role of initial conditions and policies in transition economies, World Bank Working Paper.

De Melo, Martha and Alan Gelb (1996) A Comparative analysis of twenty-eight transition economies in Europe and Asia, Post-Soviet Geography and Economics, 37, 5, 265-285.

Denizer, Cevdet (1997) Stabilization, adjustment and growth prospects in transition economies, World Bank Working Paper.

EBRD (1992) Annual economic review I992. London: European Bank for Reconstruction and Development.

EBRD (1993) Annual economic outlook 1993. London: European Bank for Reconstruction and Development.

EBRD (1997) Transition report: Enterprise performance and growth. London: European Bank for Reconstruction and Development.

EBRD (1999) Transition report update. London: European Bank for Reconstruction and Development.

EIU (1995) Mongolia. Country profile. I995. London: Economist Intelligence Unit.

EIU (1998) Serbia-Montenegro. Country profile. I998/99. London: Economist Intelligence Unit.

EIU (1999) Bosnia-Herzegovina. Country report. First quarter. London: Economist Intelligence Unit.

Energy Statistics Yearbook 1993 (1995) New York: United Nations.

Fedderke, Johannes and Robert Klitgaard (1998) Economic growth and social indicators: An exploratory analysis, Economic Development and Cultural Change, 46, 3, 455-489.

Fischer, Stanley, Ratna Sahay, and Carlos Vegh (1996) Stabilization and growth in transition economies: the early experience, Journal of Economic Perspectives, 10, 2, 45-66.

Fish, Steven (1988) The determinants of economic reform in the post-communist world, East European Politics and Societies, 12, 1, 31-78.

Foley, Michael and Bob Edwards (1999) Is it time to disinvest in social capital? Journal of Public Policy, 19, 2, 141-173.

Fukuyama, Francis (1995) Trust. New York: Free Press.

Gellner, Ernest (1997) Nationalism. New York: New York University Press.

Gorzelak, Grzegorz (1998) Regional and local potential for transformation in Poland. Warsaw: Euroreg.

Granato, Jim, Ronald Inglehart, and David Leblang (1996) The effect of cultural values on economic development: Theory, hypotheses, and some empirical tests, American Journal of Political Science, 40, 3, 607-631.

Haberler, Gottfried (1974) Economic growth and stability. Los Angeles: Nash Publishing.

Havrylyshyn, Oleh, Ivailo Izvorski, and Ron van Rooden, (1988) Recovery and growth in transition economies 1990-97 - A stylized regression analysis, IMF Working Paper WP/98/ I4I. 


\section{8o Ivan Katchanovski}

Hernandez-Cata, Ernesto (1997) Liberalization and behavior of output during the transition from plan to market, IMF Working Paper WP/97/53.

Huntington, Samuel (1996) The clash of civilizations and the remaking of world order. New York: Simon \& Schuster.

IMF (1999a) The WEO database April I 999. http://www.imf.org/external/pubs/ft/weo/1990/o1/data/growth c.csv.

IMF (1999b) World economic outlook, October I999. Washington, D.C. .: International Monetary Fund. Karatnycky, Adrian, Alexander Motyl, and Boris Shor (ed.) (1997) Nations in transit: I997: Civil society, democracy and markets in East Central Europe and the Newly Independent States. New Brunswick: Transaction Publishers.

Karatnycky, Adrian, Alexander Motyl, and Charles Graybow (ed.) (1998) Nations in transit: I998: Civil society, democracy and markets in East Central Europe and the Newly Independent States. New York: Freedom House.

Knack, Stephen and Philip Keefer (1997) Does social capital have an economic payoff? A cross-country investigation, Quarterly Journal of Economics, 11 2, 4, 1251-1288.

Knack, Stephen (1999) Social capital, growth, and poverty: A survey of cross-country evidence, Social Capital Initiative Working Paper No. 7.

Kornai, Janos (1992) The socialist system. Princeton: Princeton University Press.

Krugman, Paul (1995) Development, geography, and economic theory. Cambridge: The MIT Press.

La Porta, Rafael, Florencio Lopez-de-Silanes, Anrei Shleifer, and Robert Vishny (1977). Trust in large organizations, American Economic Review, 87, 2, 333-338.

La Porta, Rafael, Florenico Lopez-de-Silanes, Anrei Shleifer, and Robert Vishny (1999) The quality of government, Journal of Law, Economics and Organization, 15, 1, 222-279.

Lal, Deepak (1998) Unintended consequences: The impact of factor endowments, culture, and politics on long-run economic performance. Cambridge: MIT Press.

Landes, David (1998) The wealth and poverty of nations. New York: W. W. Norton.

Lavoie, Don and Emily Chamlee-Wright (1999) Culture and enterprise: The development, representation, and morality of business. Unpublished manuscript.

Leite, Carlos and Jens Weidmann (1999) Does Mother Nature corrupt? Natural resources, corruption, and economic growth, IMF Working Paper WP/99/85.

Lian, Brad and John Oneal (1997) Cultural diversity and economic development: A Cross-national study of 98 countries, 1960-1985, Economic Development and Cultural Change, 46, 1, 61-77.

Lipset, Seymour Martin, Kyoung-Ryung Seong, and John Torres (1993) A comparative analysis of the social requisites of democracy, International Social Science Journal, 45, 2, $155^{-175}$.

Lipset, Seymour Martin (1996) American exceptionalism: A double-edged sword. New York: W. W. Norton.

Lipset, Seymour Martin and Gabriel Salaman Lenz (2000) Corruption, culture, and market. In Values and human progress. Edited by Samuel Huntington and Lawrence Harrison. New York: Basic Books.

Lucas, Robert (1988) On the mechanics of economic development, Journal of Monetary Economics, $22,1,3-42$.

Mankiw, Gregory (1995) The growth of nations, Brookings Papers on Economic Activity, 1, 275326.

Miller, Arthur, Vicki Hesli, and William Reisinger (1994) Reassessing mass support for political and economic change in the former USSR, American Political Science Review, 88, 2, 399-411.

Miller, William, Stephen White and Paul Heywood (1998) Values and political change in post-communist Europe. New York: St. Martin's Press.

Mishler, William and Richard Rose (forthcoming) What are the origins of political trust? Testing institutional and cultural theories in post-communist societies, Comparative Political Studies.

North, Douglass (1990) Institutions, institutional change and economic performance. Cambridge: Cambridge University Press.

Novak, Michael (1993) The Catholic ethic and the spirit of capitalism. New York: Free Press.

O'Loughlin, John and James Bell (1999) The political geography of civic engagement in Ukraine, Post-Soviet Geography and Economics, 40, 4, 233-266.

Olson, Mancur (1982) The rise and decline of nations. New Haven: Yale University Press.

Putnam, Robert (1993) Making democracy work: Civic traditions in modern Italy. Princeton: Princeton University Press.

Raiser, Martin (1997) Informal institutions, social capital and economic transition: Reflections on a neglected dimension, EBRD Working Paper, London. 
Raiser, Martin (1999) Trust in transition, EBRD Working Paper, London.

Reisinger, William, Arthur Miller, and Vicki Hesli (1995) Public behavior and political change in post-Soviet states, Journal of Politics 57, 4, 941-970.

Romer, Paul (1986) Increasing returns and long-run growth, Journal of Political Economy, 94, 5, 1002-1037.

Rose, Richard (1992) Divisions and contradictions in economies in transition. Studies in Public Policy 206. Glasgow: University of Strathclyde.

Rose, Richard (1998) Getting things done in an anti-modern society: Social capital networks in Russia. Studies in Public Policy 304. Glasgow: University of Strathclyde.

Rose, Richard, William Mishler, and Christian Haerpfer (1998) Democracy and its alternatives: Understanding post-communist societies. Baltimore: John Hopkins University Press.

Sachs, Jeffrey and Andrew Warner (1997) Natural resource abundance and economic growth, Harvard Institute for International Development Working Paper.

Seligman, Adam (1997) The problem of trust. Princeton: Princeton University Press.

Selowsky, Marcelo and Ricardo Martin (1997) Policy performance and output growth in the transition economies, American Economic Review, 87, 2, 349-353.

Shiller, Robert, Maxim Boyko, and Vladimir Korobov (1991) Popular attitudes toward free markets: the Soviet Union and the United States compared, American Economic Review, $81,3^{8} 5^{-}$ 400 .

Shiskin, Philip (1999) Growing divisions, Wall Street Journal's Central European Review, 7, 10, $14^{-1} 5$.

Silver, Brian and Kathleen Dowley (1997) Measuring political culture in multi-ethnic societies: Reaggregating the World Values Survey, Paper presented at the annual meeting of the American Political Science Association.

Solow, Robert (1956) A contribution to the theory of economic growth, Quarterly Journal of Economics, 70, 1, 65-94.

Stuart, Robert and Christina Panayotopoulous (1999) Decline and recovery in transition economies: the impact of initial conditions, Post-Soviet Geography and Economics, 40, 4, 267-280.

Tanzi, Vito (1998) The corruption around world: Causes, consequences, scope, and cures, IMF Working Paper WP/98/63.

Taube, Gunther and Jeromin Zettelmeyer (1998). Output decline and recovery in Uzbekistan: Past performance and future prospects, IMF Working Paper WP/98/ 132 .

Temple, Jonathan (1999) The new growth evidence, Journal of Economic Literature, 37, 1, 112-156.

Transparency International (1999) 1999 bribe payers index; 1999 corruption perceptions index: http://www.transparency.de/documents/cpi/index.html.

UNECE (1998) The economic survey of Europe 3. United Nations Economic Commission for Europe.

Weber, Max (1958) Protestant ethic and spirit of capitalism. New York: Charles Scribner's Sons.

Whyte, Martin (1996) The Chinese family and economic development: Obstacle or engine? Economic development and cultural change, $45,1,1-30$.

Wilson, Andrew and Sarah Birch (1999) Voting stability, political gridlock: Ukraine's 1998 parliamentary elections, Europe-Asia Studies, 51, 6, 1999: 1039-1068.

World Bank (1993) The East Asian miracle: economic growth and public policy. Oxford: Oxford University Press.

World Resources 1996-97 (1996) New York: Oxford University Press.

World Resources 1998-99 (1998) New York: Oxford University Press.

Worldmark Encyclopedia of the Nations (1995) New York: Gale Research.

IVAN KATCHANOVSKI

The Institute of Public Policy

George Mason University

Fairfax, Virginia 22030, USA 